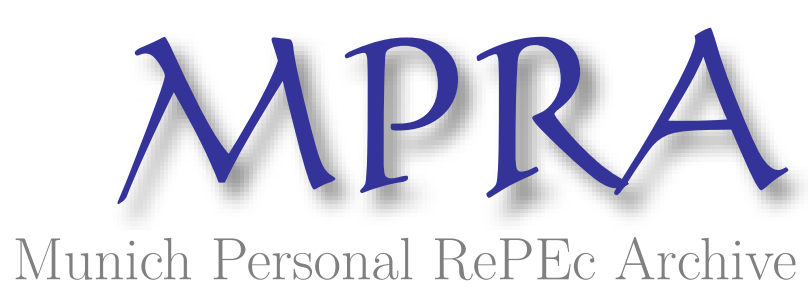

\title{
Regional Trade Agreements in East Asia: Will They Be Sustainable?
}

Park, Innwon

Korea University

February 2008

Online at https://mpra.ub.uni-muenchen.de/5068/

MPRA Paper No. 5068, posted 01 Mar 2008 14:55 UTC 


\title{
Regional Trade Agreements in East Asia: Will They Be Sustainable?*
}

\author{
Innwon Park ${ }^{* *}$
}

February 2008

\begin{abstract}
Searching for sustainable regional trade agreements (RTAs) for East Asia, we quantitatively evaluated the likely impact of proposed East Asian RTA strategies-(i) the AFTA (a being-leftalone strategy), (ii) an ASEAN Hub RTA (a hub-and-spoke type of overlapping RTA strategy), (iii) the AFTA vs a China-Japan-Korea RTA (a duplicating or competing RTA strategy), (iv) an ASEAN+3 RTA (an expansionary RTA strategy) -on the East Asian economies and the world economy with respect to consumption, production, volume of trade, and terms of trade effect by applying a multi-country and multi-sector CGE model. We found that there was no perfectly Pareto improving RTA strategy among the four different scenarios proposed for East Asia relative to the existing AFTA. However, the expansionary ASEAN+3 RTA can be a sustainable Pareto efficient policy option because the members' gains were significantly positive enough with more evenly distributed gains between members. The effects on world welfare were also positive enough and the negative effect on nonmembers was not very significant. More interestingly, if the East Asian countries are willing to cooperate with their Pacific Basin partners to form an APEC level of RTA, the evolution toward a global trade bloc can be counted as a Pareto improvement for East Asian economies in every aspect we measure.
\end{abstract}

Keywords: regional trade agreements, sustainability, Pareto efficiency, CGE model, East Asia

JEL Classification: C68, F15, O53

\footnotetext{
* This paper titled as "Proliferating Regional Trade Agreements in East Asia: Why and Whither?" was presented at the Conference on Asian Regionalism: Responding to Globalisation and China organized by Leverhulme Centre for Research on Globalisation and Economic Policy (GEP), University of Nottingham, January 16 17, 2008, the University of Nottingham in Malaysia, Kuala Lumpur, Malaysia. The author would like to thank David Greenaway, Richard Pomfret, and seminar participants for helpful comments.

** Professor, Division of International Studies at Korea University, Anam-Dong 5-1, SungbukGu, Seoul 136-701, Korea; Telephone: 82-2-3290-2406; Fax: 82-2-929-0402; Email: iwpark@korea.ac.kr.
} 


\section{Introduction}

East $^{\text {Asia }}{ }^{1}$ has been making very rapid progress in market-driven regionalization. ${ }^{2}$ Since the financial crisis occurred in 1997, East Asian effort to achieve regional economic cooperation has been very aggressive resulting in a proliferation of regionalism in East Asia. In particular, negotiating regional trade agreements (RTAs), mostly the result of the formation of bilateral free trade areas (FTAs) like a Singapore-Korea and a Japan-Malaysia FTA, and some plulilateral or multilateral FTAs like an ASEAN-China and an ASEAN-Korea FTA, are very common in the region. Accordingly, quite a few studies have dealt with East Asian regionalism focusing on why it is proliferating, what the likely impact of East Asian RTAs will be, and whether East Asian RTAs can lead us to global free trade or not. ${ }^{3}$ However, they do not ask whether the existing or proposed East Asian RTAs will be sustainable in the long run. In other words, none of existing studies quantitatively analyzes if there exist sustainable RTAs for East Asia in a globalizing world among the major RTAs considered in East Asia.

As a prerequisite, for the sustainability of RTAs, the effectiveness of a policy for participating countries is a necessary condition to be satisfied. To be an effective RTA, the RTA should create a significant enough positive welfare effect on all the participating member countries and evenly distribute the gains from free trade between members as we consider the welfare gains that are not transferable across borders. Next, what is the sufficient condition for sustainability? The RTA should create positively enough static and dynamic effects on world welfare leading the RTAs to nondiscriminatory global free trade as Bhagwati (1993) indicates. Otherwise, the RTA will easily stall and be ineffective as time passes. Last but not least, the sustainable RTA could be more desirable provided that the Pareto efficiency holds. If not, there will be no incentive for possible members of an RTA to start negotiation for any alternative evolution of RTAs and to trigger the domino effect of regionalism ${ }^{4}$ by moving from an existing trade bloc to another.

Even though most existing studies have missed examining sustainability, there are some exceptions. The global welfare gains from East Asian RTAs have been tested by Lee and

\footnotetext{
${ }^{1}$ In this paper, we narrowly define East Asia by including ASEAN 10 countries in Southeast Asia and China, Japan, and Korea in Northeast Asia. In addition, we treat the ASEAN 10 countries as an economy. Thus there exist 4 individual East Asian economies in this paper, namely ASEAN+3 including ASEAN, China, Japan, and Korea.

2 For the market-driven regionalization, see Urata (2006).

3 For proliferating RTAs in East Asia, see JETRO (2003), Lu (2003), Kawai (2004), Feridhanusetyawan (2005), and Lee and Park (2005).

${ }^{4}$ See Baldwin (1993).
} 
Shin (2006) with a gravity regression analysis and by Park (2006) with a computable general equilibrium (CGE) model analysis for East Asian economies as a whole. However, they have not evaluated effectiveness, as a prerequisite, by analyzing the welfare effect on each economy in East Asia and then they have ignored an examination of the possible Pareto improvement. Our work, described in this paper, is an attempt to fill this gap by empirically testing the sustainability of possible East Asian RTAs.

Each of the East Asian countries may consider the following four different RTA strategies: (i) no further effort to liberalize the regional market and then the existing AFTA will be activated in the region ("being-left-alone strategy"); (ii) the ASEAN+1 approach will likely completed as Japan successfully forms an RTA with ASEAN soon and then builds an ASEAN Hub RTA web including an ASEAN+China, an ASEAN+Japan, and an ASEAN+Korea FTA ("hub-and-spoke type 5 of overlapping RTA strategy"); (iii) the Northeast Asian three countries will form their own separate RTA competing against ASEAN, that is, the AFTA versus a China-Japan-Korea FTA (“duplicating or competing RTA strategy”); (iv) the ASEAN, as a whole, and the three Northeast Asian countries cooperate with each other to form an East Asian FTA, that is, ASEAN+3 RTA ("expansionary RTA strategy").

Searching for the sustainable RTA for East Asia, what is the most desirable RTA strategy? In order to find the answer, we should consider interests of all the parties involved individually and altogether. In this paper, we describe our quantitative test of the sustainability of proposed East Asian RTAs with respect to the above-mentioned four conditions: (i) country-specific gains, (ii) distribution of gains between members, (iii) global welfare gains, and (iv) Pareto efficiency. More specifically, we quantitatively evaluate the likely effect of the proposed strategies on the East Asian economies with respect to the equivalent variation of welfare, GDP, exports, imports, and income terms of trade by applying a multi-country and multi-sector CGE model. ${ }^{6}$ The CGE model analysis has an advantage in measuring the welfare effect directly and in comparing the possible outcomes of different scenarios while maintaining logical consistency even though the complicated ex-ante simulation methodology sometimes mis-specifies the model economy.

The paper is organized as follows. Section II provides a brief discussion of the main characteristics of East Asian RTAs and of the debated issues about proliferating RTAs in East

\footnotetext{
${ }^{5}$ For the general concept of the hub-and-spoke RTAs, see Lloyd (2002), Umemoto (2003), and Baldwin (2004).

${ }^{6}$ For East Asian RTAs with CGE models, see McKibbin (1998), Scollay and Gilbert (2001), Urata and Kiyota (2003), McKibbin, Lee, and Cheong (2004), Sulamaa and Widgrén (2005), Zhai (2006), Park (2006), and Kawai and Wignaraja (2007).
} 
Asia. Section III introduces the CGE model adopted, data used, and ex-ante scenarios designed. Section IV quantitatively measures the effects of the proposed East Asian RTAs' strategies and evaluates the sustainability. Section V presents concluding remarks with policy implications.

\section{Regional Trade Agreements in East Asia}

\section{Main Characteristics of East Asian RTAs}

Both intra- and inter-regional trade agreements are proliferating in East Asia as shown in Table 1. As of September 2007, 21 RTAs have been implemented, 8 RTAs have been signed, and more than three dozen RTAs are being negotiated or considered by East Asian countries. There are some distinguishing characteristics that we may derive from the RTAs including countries in East Asia.

First, this trend of reducing or eliminating trade barriers between members is relatively new in East Asia. Most of the East Asian countries, especially countries in Northeast Asia, have been well-known to prefer nondiscriminatory multilateral liberalization efforts rather than a discriminatory regional liberalization policy. However, after realizing the importance of regional economic cooperation from the East Asian financial crisis in 1997, East Asian countries have changed their policy stance from favoring a global approach to favoring a regional approach. As in Table 1, among the 29 RTAs implemented or signed including East Asian countries, 28 RTAs, excluding the AFTA, have been implemented after the crisis. Second, most of RTAs in East Asia have taken a form of bilateral negotiation similar to the world-wide trend of seeking a cheaper and easier negotiation cost even though the gains from freer trade are limited. Third, there has been no distinction between intra- and inter-regional partnerships. Recent innovations in information and communication technology significantly have saved transaction costs and made geographical distance relatively less important. Pre-RTA economic interdependence has been more important as we have considered the right partners to approach for the formation of a RTA. Fourth, considering the partnership issue of RTAs again, most of East Asian RTAs have been taking the form of hub- 
and-spoke type of overlapping RTAs which may cause a spaghetti bowl phenomenon. ${ }^{7}$ In particular, ASEAN, Singapore, and Thailand have been very aggressive in pursuing being a hub. Fifth, there has been very slow progress in making an expansionary path of RTAs which may trigger a domino effect of regionalism. The proposed ASEAN+3 RTAs are still under consideration as a talking point.

\section{Why are RTAs Proliferating in East Asia?}

As we mentioned earlier, recognizing the necessity for regional economic cooperation for regional economic stability and revitalization of the regional economic dynamism since the East Asian financial crisis can be one of the most important market-driven motives found in East Asia. The deepening intra-regional interdependence can be another major factor to trigger the shift in the policy stance. The intra-regional trade share in ASEAN+3 has been steadily rising from 29.4 percent in 1990 to 37.3 percent in 2000 , to 38.9 percent in 2005 , and 38.3 percent in $2006 .^{8}$

Furthermore, the strong incentives for a country to be a hub of a RTA web make both individual Southeast Asian countries and ASEAN as a whole aggressively seek to initiate multiple negotiations for RTAs. On the other hand, the fear to be left alone from the worldwide movement toward regionalism has made most East Asian countries competitively jump on the wagon.

A disappointing outcome produced by multilateral institutions' efforts for global free trade such as the stalled DDA negotiation under the WTO and the sluggish achievement of the Bogor Goals under APEC also has pushed East Asia's pursuit of regional cooperation. Leadership competition between China and Japan can be listed as an important political factor behind East Asian regionalism.

\section{Whither East Asian RTAs?}

Carefully analyzing the recent change in the regional trade pattern of East Asia, Urata (2006) finds an increasing trend of intra-regional trade, trade in the manufacturing sector, vertical intra-industry trade, and trade in manufacturing parts and components between

\footnotetext{
7 See Bhagwati, Greenaway, and Panagariya (1998) and Panagariya (1999) for the spaghetti bowl phenomenon caused by overlapping RTAs.

${ }^{8}$ See Table 1 in Kawai (2007).
} 
countries in East Asia. Considering the recent changes, we may expect that (i) the rising preRTA intra-regional trade volume will cause a stronger trade creation effect, (ii) the increasing volume of trade in the manufacturing sector will improve economic efficiency from having a more competitive regional market environment, (iii) the increasing vertical intra-industry trade will result in bigger short-term gains from economies of scale, and (iv) the resulting trade in manufacturing parts and components that is closely connected to the supply chain and higher productivity growth expected from an international division of labor will also enhance economic efficiency and bring bigger gains from regional free trade. In sum, the expected positive effects of the recent changes in the region can be counted as having more favorable conditions for the formation of RTAs in East Asia. By estimating with a gravity regression analysis, Lee and Park (2005) and Lee and Shin (2006) support the facts observed in East Asia. They argue that most of East Asian RTAs will create more intra-bloc trade, will not divert extra-bloc trade, and will lead to global free trade.

However, there are some important impediments to be considered. The currently proliferating East Asian RTAs have been initiated mostly by the private sector oriented toward profit-seeking motives unlike the European case for political and ideological harmonization. It makes the formation of an institutional framework for regional integration difficult in East Asia. In addition, the hub-and-spoke type of many overlapping RTAs in East Asia could result in the spaghetti bowl phenomenon of discriminatory trade blocs that have the potential to be stumbling blocs against global free trade. More specifically, Park (2006) quantitatively evaluated the effects of the proposed East Asian RTAs by applying a CGE model analysis. Park proposed that East Asian RTAs should take an expansionary path, for example an ASEAN+3 RTA, to establish a building bloc for global free trade in contrast to competing to achieve the first mover advantage or hub self-interest resulting from duplicating or overlapping RTAs. Baldwin (2004) and Zhai (2006) have also highlighted the negative welfare effect expected from overlapping RTAs in East Asia. Recently, Kawai (2007) and Kawai and Wignaraja (2007) suggest that either an ASEAN+3 (the East Asian Summit countries) or an ASEAN+6 (including Australia, New Zealand, and India) FTA is a desirable economic architecture in East Asia by maximizing the positive gains from trade liberalization and minimizing the negative "noodle bowl" effects of regionalism. ${ }^{9}$

\footnotetext{
${ }^{9}$ They, however, propose to achieve the bigger trade blocs by utilizing ASEAN as the hub for the integration such as the 3 sets of ASEAN+1 FTA which is not desirable based on the empirical analysis in this paper.
} 


\section{Computable General Equilibrium (CGE) Model}

\section{Model and Data}

What will be the effect of the proposed East Asian RTAs on each of the East Asian countries considered in this paper-ASEAN, China, Japan, and Korea? Are there any sustainable RTAs or a RTA when we evaluate the possible outcomes? The answers to these questions are formed by assessing the macroeconomic aggregate effects of the proposed East Asian RTA strategies by applying a traditional static CGE model simulation technique. We have adopted a trade-linked multi-sector and multi-country CGE model in order to measure the impact of East Asian regional economic integration efforts on welfare, GDP, exports, and income terms of trade. We carefully have selected those four aggregate variables to measure the effectiveness of proposed strategies by type of RTAs and by the economies considered. The equivalent variations of welfare have been selected mainly for the consumption effect, GDP is mainly for the production effect. Exports have been chosen for the volume of trade effect. Income terms of trade ${ }^{10}$ is another important measure of welfare change. In addition, we report on the effect on imports and bilateral trade pattern to support our findings.

The CGE model we describe in this section is the "GTAP6inGAMS" model developed by Rutherford (2005). The model has three economic agents: producer, representative consumer (private and public), and trading partners. The GTAP6inGAMS model is a traditional static Arrow-Debreu type of general equilibrium model in which the zero profit condition and market clearance define the equilibrium. The GTAP6inGAMS is a modified version of the GTAP model version 6 developed for GAMS users. The current model described in this paper uses a classification consisting of 7 sectors and 25 economies the same as Park (2006). ${ }^{11}$ The model solution has been calibrated, with 2001 as the base year, using Global Trade, Assistance, and

${ }^{10}$ Income terms of a trade measure, the purchasing power of exports in terms of imports, can be a better measure of income or welfare effect of price changes in international trade, especially for developing countries, relative to the net barter terms of trade. See pp 136-137 in Chacholiades (1990).

${ }^{11}$ The 7 sectors are Agricultural Products, Food Products, Extractive Industry, Light Manufacturing, Heavy Manufacturing, Technology-intensive Manufacturing, and Services. The 27 economies are Indonesia, Malaysia, Philippines, Singapore, Thailand, Vietnam, the Rest of Southeast Asia, China, Japan, Korea, Hong Kong, Taiwan, Australia, Brazil, Canada, Chile, India, Mexico, New Zealand, Peru, Russia, the United States of America, the European Free Trade Association, the Western European Countries, and the Rest of the World. For more detailed classification, see Park (2006). 
Production (The GTAP 6 Database) ${ }^{12}$. The model has been implemented using the GAMS MPSGE. $^{13}$

\section{Scenarios}

As introduced by Lee, Park and Shin (2004) and applied to the East Asian case by Park (2006), the proliferating RTAs in East Asia will mainly take the following three different paths: expansionary RTAs, where the membership of existing RTAs are increasing by attracting new members; duplicating (or competing) RTAs where separate RTAs are created between nonmembers of existing RTAs and competing with existing RTAs; and overlapping RTAs, where some members are focusing on being a hub for the RTAs, by forming multiple membership with countries in the region. More specifically, the existing AFTA can be expanded to a bigger trade bloc such as an ASEAN+3 RTA. Some RTAs, such as those between China-Japan-Korea, will be formed in the near future, by competing with existing RTAs such as the AFTA. Some RTAs, similar to the ASEAN-China, ASEAN-Korea, and ASEAN-Japan RTAs, which will have overlapped membership making the ASEAN a hub of East Asian RTAs.

In order to quantitatively measure the impacts of the proposed East Asian RTAs on welfare, output production, and trade flows for each of the participating countries, members as a whole, nonmembers, and the world economy, we empirically designed and tested four scenarios. . For each of the scenarios, both import tariffs and export taxes between members were eliminated, but the trade barriers between members and nonmembers were retained. The scenarios we examine are as follows.

- [AFTA]: An FTA among the ASEAN countries as a reference (the being-left-alone RTA strategy)

- [ASEAN Hub]: Three separate FTAs including an ASEAN-China, an ASEAN-Japan, and an ASEAN-Korea FTAs, assuming that the AFTA is effective (the hub-and-spoke type of overlapping RTA strategy)

- [AFTA vs China-Japan-Korea]: Two separate FTAs including the AFTA and a ChinaJapan-Korea FTA (the duplicating or competing RTA strategy)

12 See Dimaranan and McDougall (2006).

13 MPSGE (Mathematical Programming System for General Equilibrium analysis) is a subsystem within GAMS. See http://www.gams.com/solvers/mpsge/index.htm. 
- [ASEAN+3]: An FTA among the ASEAN, China, Japan, and Korea (the expansionary RTA strategy)

For the base solution of the model economy, we ran the CGE model without changing its initial condition and derived general equilibrium values for each of the economies in the model. As a next step, we reran the model under different scenarios and recalculated the equilibrium values for each case. Then we compared the different equilibrium values with the initial base solution in terms of percentage deviation from the base to evaluate the experimental impacts of each scenario on each country.

\section{In Search of Sustainable RTAs in East Asia: Scenario Analysis}

\section{Aggregate Effect}

Table 2 provides a comparative summary of aggregate economic effects of the proposed East Asian RTAs by type of RTA. The aggregate effect of the currently effective AFTA had no significant negative effects for the discriminatory liberalization on the Northeast Asian neighbors but produced significant enough positive gains to ASEAN members. However, if ASEAN members decided to go further by pursuing the ASEAN Hub scenario which included 3 sets of ASEAN+1 FTAs, it can remarkably raise the ASEAN's gains from free trade. The ASEAN's welfare and GDP gains can be raised by over 3 times bigger than that of the AFTA. The negative effects on excluded neighbors will be more troublesome even though the neighboring countries can increase their exports by the income effect coming from the additional GDP gains of ASEAN as shown to be in the increase in bilateral trade volume between ASEAN and each of the three Northeast Asian countries.

Considering the negative effects expected from AFTA or the ASEAN Hub scenario, the Northeast Asian neighbors may decide to form their own regional protection strategy against ASEAN by forming a China-Japan-Korea FTA. The trade warfare between the two regions will be harmful to the less developed ASEAN economy and will give huge benefit to the Northeast Asian countries, especially Korea. However, this duplicating RTA competition may not be beneficial to the world economy at all. It will cause much lower welfare gains to the world economy than that of the existing AFTA and ASEAN Hub scenario. On the other hand, if those 
neighboring countries in both Southeast and Northeast Asia cooperate with each other by forming an East Asian trade bloc, the so called ASEAN+3 FTA, it will be beneficial to all the participating countries except for its negative welfare effect on China. The negative welfare effect of all the four proposed East Asian RTAs on China is a very interesting result which is also highlighted by Zhai (2006). It can be explained by the heavy and increasing intra-regional dependence of imported parts and components to China as a world factory. In addition, East Asian RTAs reallocate resources from the manufacturing industry to the agricultural industry within China and it may deteriorate economic efficiency of the Chinese manufacturing sector resulting in the deterioration of welfare as Zhai (2006) mentioned.

In terms of the trade effect including volumes measured by the growth of exports and imports, the income terms of trade, and bilateral trade relations, all the proposed East Asian RTAs have a positive effect on participating countries and the world economy as a whole.

Figure 1 compares the aggregate effects of the four proposed East Asian RTAs on the four regional economies in terms of the equivalent variation of welfare, GDP, exports, and income terms of trade. The ASEAN gains the most from the existing AFTA and an ASEAN Hub scenario. This finding explains why most of the nonmembers of RTAs fear being left alone. This fear motivates nonmembers to jump on the RTA band wagon. This finding explains why countries are competing to be a hub and making a very complicated overlapping RTA map. There is no distinguishing difference in the effects of an AFTA between nonmembers of the RTA but the effects of an ASEAN Hub RTA will cause a relatively better effect on China. The competing Northeast Asian RTA and the expansionary East Asian RTA will distribute relatively more favorable gains to Korea and China when we measure the size of the rectangles. The ASEAN will benefit least of the competing and expansionary RTA strategies.

Figure 2 illustrates Table 2 by highlighting which scenario is the best for each of the economies in East Asia. For the sake of the ASEAN, the ASEAN Hub RTA is the best and competing with the Northeast Asian neighbors is the worst scenario. For the three Northeast Asian countries, the ASEAN+3 RTA will be the most desirable RTA but it is not much better than the Northeast Asian RTA between the three countries competing against the AFTA. Both the AFTA and ASEAN Hub RTA will be the worst scenarios for the countries in Northeast Asia.

In search of a sustainable RTA from the proposed four scenarios, Figure 3 illustrates the effect of the East Asian RTAs by aggregate economic variables representing each country's welfare. In terms of the equivalent variation of welfare and income terms of trade, there is no Pareto efficient RTA among the four different scenarios possible in East Asia. 
Reallocating resources from an existing AFTA to any alternative trade bloc may hurt at least one economy in the region. However, in terms of the GDP, the expansionary ASEAN+3 RTA can be a Pareto efficient scenario where the shift from the AFTA to the bigger trade bloc can make all the participating economies better off. For export promotion raising trade volume, both the ASEAN Hub and the ASEAN+3 RTA can be counted as Pareto improving RTA strategies. However, ASEAN+3 is more superior with respect to Pareto efficiency than the ASEAN Hub RTA. Even though our search for the Pareto efficient RTA in East Asia has proven to be unsuccessful, we still have a partially acceptable Pareto efficient RTA, the ASEAN+3 RTA. More interestingly, if we expand the regional liberalization effort toward a global level including the Pacific Basin partners, that is, an APEC RTA, the APEC RTA can be a Pareto efficient RTA for the economies in East Asia in every aspect we have measured as indicated in Table 2.

\section{East Asian RTAs in a Globalizing World}

Will the proposed East Asian RTAs be beneficial to the members as a whole and the world economy? If not, the proposed East Asian RTAs may not be effective and sustainable. As presented in Table 3, all the proposed East Asian RTAs raise world welfare between a minimum of 0.21 percent in the case of the competing RTAs, including the AFTA and the China-Japan-Korea RTA, and a maximum of 0.98 percent in the case of the ASEAN Hub RTA. The GDP gains range from 0.01 percent for the AFTA to 0.57 percent for the ASEAN+3 RTA. The world trade volume also rises. The expansionary ASEAN+3 RTA can be evaluated as the best strategy for maximizing world output and trade. For the members' welfare, GDP, and trade as in Table 3, the expansionary ASEAN+3 RTA is also the best strategy for East Asian participants in terms of creating bigger gains in many aspects and more evenly distributed gains between the Southeast and Northeast Asian members.

In summary, considering the effects of the ASEAN+3 RTA on members, nonmembers, and the world economy relative to other alternative strategies, the partially Pareto efficient East Asian RTA-ASEAN+3 FTA- can be effective and sustainable because the effect on members is significantly positive enough and more evenly distributed, the effects on the world welfare is positive enough, and the negative effect on nonmembers is not very significant.

\section{Sectoral Effect}


The effect of the proposed East Asian RTAs on output production by sector is summarized in Table 4 as supporting material. In terms of domestic output production, Korea benefits the most and there are no significant losers. If we focus on the ASEAN+3 RTA, the East Asian regional integration restructures the regional industrial structure based on each economy's comparative advantages. ASEAN and China's primary industries, Japanese advanced manufacturing industries, and Korea's light manufacturing industries will achieve more gains. This finding also supports the above-mentioned deteriorated welfare of China caused by resource reallocation across industries.

\section{Concluding Remarks}

Searching for effective and sustainable RTAs or a RTA for East Asia, we quantitatively evaluated the likely effect of the proposed RTA strategies-(i) the AFTA (the being-left-alone strategy), (ii) an ASEAN Hub RTA (the hub-and-spoke type of overlapping RTA strategy), (iii) the AFTA vs a China-Japan-Korea RTA (the duplicating or competing RTA strategy), (iv) an ASEAN+3 RTA (the expansionary RTA strategy)—on East Asian economies with respect to the equivalent variation of welfare, GDP, exports, imports, and income terms of trade by applying a multi-country and multi-sector CGE model. ${ }^{14}$

From the ex-ante simulation analysis testing for the sustainability of the proposed East Asian RTAs and reflected in Table 5, we found that both the duplicating and expansionary RTA strategy by forming the Northeast Asian RTA separately from the existing AFTA and the ASEAN+3 RTA, respectively, were desirable strategies for both the East Asian economies and the world economy. Even though the ASEAN Hub strategy appeared to a better policy option for ASEAN and the world economy, it was not necessarily a desirable strategy when we considered the neighboring countries in Northeast Asia as spokes.

14 There exist some limitations in this research. In addition to the four measures we selected for the Pareto efficiency, there are many other important variables to be considered. If we use different measures, our conclusion and policy implications may not be valid. Moreover, the partial Pareto efficiency may not hold if we consider all the ASEAN members independently. These limitations should be carefully considered when we evaluate policy implications in this paper. 
We also found that there was no perfectly Pareto efficient RTA among the four different scenarios possible in East Asia. However, in terms of the production effect and trade volume effect of welfare, the expansionary ASEAN+3 RTA can be a sustainable Pareto efficient scenario where the evolution from AFTA to the bigger trade bloc can make all the participants better off. Furthermore, when we evaluated the effects of the ASEAN+3 RTA on members, nonmembers, and the world economy relative to other alternative strategies, the partially Pareto improving East Asian RTA would be more desirable because the members gains were significantly positive enough and more evenly distributed between members, the effects on the world welfare were also positive enough, and the effect on nonmembers was not strongly negative. Moreover, we found that the evolution of the regional RTA to the global level such as an APEC RTA, could be a Pareto improvement for the economies in East Asia. 


\section{References}

Baldwin, Richard. 1993. “A Domino Theory of Regionalism," NBER Working Paper Series 4465 .

Baldwin, Richard. 2004. "The Spoke Trap: hub and spoke bilateralism in East Asia," KIEP CNAEC Research Series 04-02, Korea Institute for International Economic Policy (KIEP).

Bhagwati, Jagdish. 1993. "Regionalism and Multilateralism: an overview," Chapter 2 in New Dimensions in Regional Integration edited by Jaime De Melo and Arvind Panagariya, Centre for Economic Policy Research (CEPR), Cambridge University Press, pp. 22-51. Bhagwati, Jagdish, David Greenaway and Arvind Panagariya. 1998. “Trading Preferentially: Theory and Policy.” The Economic Journal, 108, pp. 1128-1148.

Chacholiades, Miltiades. 1990. International Economics, McGraw-Hill Publishing Company, New York.

Dimaranan, Betina V. and Robert A. McDougall, Editors (2006, forthcoming). Global Trade, Assistance, and Production: The GTAP 6 Data Base, Center for Global Trade Analysis, Purdue University.

Feridhanusetyawan, Tubagus. 2005. "Preferential Trade Agreements in the Asia-Pacific Region.” IMF Working Paper WP/05/149.

JETRO. 2003. "Prospects for Free Trade Agreements in East Asia," Overseas Research Department, Japan External Trade Organization.

Kawai, Masahiro. 2004. "Regional Economic Integration and Cooperation in East Asia," paper prepared for the Experts' Seminar on the Impact and Coherence of OECD Country Policies on Asian Developing Economies.

Kawai, Masahiro. 2007. "Evolving Economic Architecture in East Asia," ADB Institute Discussion Paper No. 84, ADB Institute.

Kawai, Masahiro and Ganeshan Wignaraja. 2007. "ASEAN+3 or ASEAN+6: Which Way Forward?” ADB Institute Discussion Paper No. 77, ADB Institute.

Lee, Jong-Wha and Innwon Park. 2005. "Free Trade Areas in East Asia: Discriminatory or Nondiscriminatory?" The World Economy, 28:1, pp. 21-48.

Lee, Jong-Wha, Innwon Park and Kwanho Shin. 2004. "Proliferating Regional Trade Arrangements: Why and Whither?" mimeo.

Lee, Jong-Wha and Kwanho Shin. 2006. "Does regionalism lead to more global trade integration in East Asia?" The North American Journal of Economics and Finance, 
17:3, pp. 283-301.

Lloyd, Peter. 2002. "New Bilateralism in the Asia-Pacific," The World Economy, 25, pp.12791296.

Lu, Feng. 2003. "Free Trade Area: Awakening regionalism in East Asia," Working Paper Series E2003010, China Center for Economic Research.

McKibbin, Warwick J. 1998. "Regional and Multilateral Trade Liberalization: The Effects on Trade, Investment and Welfare," in Europe, East Asia and APEC: A Shared Global Agenda? edited by Peter Drysdale and D. Vines. Cambridge University Press, pp.195-220.

McKibbin, Warwick J., Jong-Wha Lee, and Inkyo Cheong. 2004. “A Dynamic Analysis of a Korea-Japan Free Trade Area: Simulations with the G-Cubed Asia-Pacific Model,” International Economic Journal, 18, pp. 3-32.

Panagariya, Arvind. 1999. "The Regionalism Debate: An Overview,” The World Economy, 22, pp. $477-511$

Park, Innwon. 2006. "East Asian Regional Trade Agreements: Do They Promote Global Free Trade?" Pacific Economic Review, 11: 4, pp. 547-568.

Rutherford, Thomas F. 2005. "GTAP6inGAMS: The Dataset and Static Model,” paper prepared for the Workshop on Applied General Equilibrium Modelling for Trade Policy Analysis in Russia and the CIS.

Scollay, Robert, and John Gilbert. 2001. New Subregional Trading Arrangements in the AsiaPacific, Washington, DC: Institute for International Economics.

Sulamaa, Pekka and Mika Widgrén. 2005. “Asian Regionalism versus Global Free Trade: A Simulation Study on Economic Effects," Discussion Papers, The Research Institute of the Finnish Economy.

Umemoto, Masaru. 2003. "Hub and Spoke Integration and Income Convergence," Working Paper Series 2003-01. The International Center for the Study of East Asian Development (ICSEAD).

Urata, Shujiro and Kozo Kiyota. 2003. "The Impact of an East Asia FTA on Foreign Trade in East Asia," NBER Working Paper Series 10173, National Bureau of Economic Research.

Urata, Shujiro. 2006. “A Shift from Market-driven to Institution-driven Regionalization in East Asia," Mimeo.

Zhai Fan. 2006. "Preferential Trade Agreements in Asia: Alternative Scenarios of 'Hub and Spoke." ERD Working Paper No. 83. ADB. 
Table 1. Major RTAs including Countries in East Asia as of September 2007

\begin{tabular}{|c|c|c|c|}
\hline Implemented (year into force) & Signed (year of signing) & Under Negotiation & Under Consideration \\
\hline $\begin{array}{c}\text { Bilateral and Intra-Regional } \\
\text { China-Hong Kong (2004) } \\
\text { China-Macao (2004) } \\
\text { Japan-Malaysia (2006) } \\
\text { Singapore-Japan (2002) } \\
\text { Singapore-India (2005) } \\
\text { Singapore-Korea (2006) }\end{array}$ & $\begin{array}{l}\text { China-Pakistan (2006) } \\
\text { Japan-Philippines (2006) } \\
\text { Japan-Brunei (2006) } \\
\text { Japan-Thailand (2007) } \\
\text { Thailand-India (2004) }\end{array}$ & $\begin{array}{l}\text { China-Singapore } \\
\text { Japan-Indonesia } \\
\text { Japan-Korea } \\
\text { Japan-India } \\
\text { Japan-Vietnam } \\
\text { Korea-India } \\
\text { Singapore-Kuwait } \\
\text { Singapore-Pakistan } \\
\text { Singapore-Qatar } \\
\text { Thailand-India }\end{array}$ & $\begin{array}{c}\text { China-India } \\
\text { China-Korea } \\
\text { China-Thailand } \\
\text { Japan-Taiwan } \\
\text { Singapore-Bahrain } \\
\text { Singapore-Sri Lanka } \\
\text { Singapore-UAE } \\
\text { Thailand-Pakistan }\end{array}$ \\
\hline $\begin{array}{c}\text { Bilateral and Inter-Regional } \\
\text { China-Chile (2006) } \\
\text { Japan-Mexico (2005) } \\
\text { Korea-Chile (2002) } \\
\text { Singapore-Australia (2003) } \\
\text { Singapore-Jordan (2005) } \\
\text { Singapore-New Zealand (2001) } \\
\text { Singapore-US (2004) } \\
\text { Singapore-Panama (2006) } \\
\text { Thailand-Australia (2006) } \\
\text { Thailand-New Zealand (2005) }\end{array}$ & $\begin{array}{l}\text { Japan-Chile (2007) } \\
\text { Korea-US (2007) } \\
\text { Thailand-Peru (2005) }\end{array}$ & $\begin{array}{c}\text { China-Australia } \\
\text { China-New Zealand } \\
\text { Japan-Australia } \\
\text { Japan-Canada } \\
\text { Japan-Swiss } \\
\text { Korea-Canada } \\
\text { Korea-Mexico } \\
\text { Singapore-Canada } \\
\text { Singapore-Mexico } \\
\text { Singapore-Peru } \\
\text { Thailand-US }\end{array}$ & $\begin{array}{l}\text { China-Island } \\
\text { Korea-Australia } \\
\text { Singapore-Moroco } \\
\text { Singapore-Egypt } \\
\text { Thailand-Chile }\end{array}$ \\
\hline $\begin{array}{c}\text { Plurilateral and Intra-Regional } \\
\text { AFTA (1992) } \\
\text { ASEAN-China (2005) } \\
\text { ASEAN-Korea (2007) }\end{array}$ & & $\begin{array}{c}\text { ASEAN-India } \\
\text { ASEAN-Japan } \\
\text { China-GCC } \\
\text { Japan-GCC }\end{array}$ & $\begin{array}{c}\text { ASEAN+3 } \\
\text { ASEAN-Taiwan } \\
\text { China-Japan-Korea } \\
\text { Singapore-GCC }\end{array}$ \\
\hline $\begin{array}{c}\text { Plurilateral and Inter-Regional } \\
\text { Korea-EFTA (2006) } \\
\text { Singapore-EFTA (2003) }\end{array}$ & & $\begin{array}{c}\text { ASEAN-CER } \\
\text { Korea-EU } \\
\text { Korea-EU }\end{array}$ & $\begin{array}{c}\text { ASEAN-EFTA } \\
\text { ASEAN-EU } \\
\text { ASEAN-US } \\
\text { Korea-MERCOSUR } \\
\text { Singapore-EU } \\
\text { Thailand-EFTA }\end{array}$ \\
\hline
\end{tabular}

Notes: AFTA - ASEAN Free Trade Area; ASEAN - Association of South East Asian Nations;

ASEAN+3 - ASEAN plus China, Japan, Korea; CER - Closer Economic Relations between Australia and New Zealand; EFTA - European Free Trade Association; EU - European Union; GCC - Gulf Cooperation Council; MERCUSOR - Southern Common Market

Sources: Compiled mainly based on the WTO Web site and http://www.bilaterals.org. 
Table 2. The Effects of the Proposed East Asian RTAs on the Participating Economies (\% Deviation from the Base)

\begin{tabular}{|c|c|c|c|c|c|c|c|c|c|c|c|}
\hline \multirow{2}{*}{\multicolumn{2}{|c|}{ Existing RTA }} & \multirow{3}{*}{$\begin{array}{c}\text { Welfare (EV) } \\
1.06\end{array}$} & \multirow{3}{*}{$\begin{array}{l}\text { GDP } \\
1.45\end{array}$} & \multirow{3}{*}{$\begin{array}{c}\text { Exports } \\
2.22\end{array}$} & \multirow{3}{*}{$\begin{array}{c}\text { Imports } \\
2.90\end{array}$} & \multirow{3}{*}{$\begin{array}{c}\text { Income Terms of } \\
\text { Trade } \\
4.30\end{array}$} & \multicolumn{5}{|c|}{ Bilateral Trade } \\
\hline & & & & & & & \multirow{2}{*}{$\frac{\text { ASEAN }}{23.01}$} & \multirow{2}{*}{$\begin{array}{l}\text { China } \\
-4.34\end{array}$} & \multirow{2}{*}{$\begin{array}{l}\text { Japan } \\
-2.86\end{array}$} & \multirow{2}{*}{$\begin{array}{c}\text { Korea } \\
-3.66\end{array}$} & \multirow{2}{*}{$\begin{array}{c}\text { World } \\
0.15\end{array}$} \\
\hline \multirow{5}{*}{ AFTA } & ASEAN & & & & & & & & & & \\
\hline & China & -0.06 & -0.07 & -0.08 & -0.19 & -0.04 & -4.34 & & 0.26 & 0.28 & -0.13 \\
\hline & Japan & -0.02 & -0.05 & -0.13 & -0.21 & -0.18 & -2.86 & 0.26 & & 0.30 & -0.17 \\
\hline & Korea & -0.06 & -0.08 & -0.13 & -0.18 & -0.14 & -3.66 & 0.28 & 0.30 & & -0.15 \\
\hline & World & 0.28 & 0.02 & 0.09 & 0.09 & & 0.15 & -0.13 & -0.17 & -0.15 & 0.08 \\
\hline \multirow{2}{*}{\multicolumn{2}{|c|}{ Overlapping RTA (Hub and Spoke) }} & \multirow{2}{*}{ Welfare (EV) } & \multirow{2}{*}{ GDP } & \multirow{2}{*}{ Exports } & \multirow{2}{*}{ Imports } & \multirow{2}{*}{$\begin{array}{c}\text { Income Terms of } \\
\text { Trade }\end{array}$} & \multicolumn{5}{|c|}{ Bilateral Trade } \\
\hline & & & & & & & ASEAN & China & Japan & Korea & World \\
\hline \multirow{5}{*}{ ASEAN Hub } & ASEAN & 3.77 & 4.78 & 2.59 & 5.22 & 4.21 & 16.32 & 51.02 & 2.13 & 4.53 & 2.33 \\
\hline & China & -0.58 & -0.19 & 3.23 & 3.21 & 5.16 & 51.02 & & -2.49 & -4.79 & 3.22 \\
\hline & Japan & -0.09 & -0.24 & 0.49 & 0.02 & 1.48 & 2.13 & -2.49 & & 0.27 & 0.27 \\
\hline & Korea & -0.33 & -0.30 & 0.23 & -0.12 & 0.91 & 4.53 & -4.79 & 0.27 & & 0.07 \\
\hline & World & 0.98 & 0.06 & 0.29 & 0.29 & & 2.33 & 3.22 & 0.27 & 0.07 & 0.24 \\
\hline \multirow{2}{*}{\multicolumn{2}{|c|}{ Duplicating (Competing) RTA }} & \multirow{2}{*}{ Welfare (EV) } & \multirow{2}{*}{ GDP } & \multirow{2}{*}{ Exports } & \multirow{2}{*}{ Imports } & \multirow{2}{*}{$\begin{array}{c}\text { Income Terms of } \\
\text { Trade }\end{array}$} & \multicolumn{5}{|c|}{ Bilateral Trade } \\
\hline & & & & & & & ASEAN & China & Japan & Korea & World \\
\hline \multirow{5}{*}{ AFTA vs China-Japan-Korea } & ASEAN & 0.38 & 0.89 & 2.03 & 2.34 & 4.02 & 25.02 & -14.35 & -6.13 & -11.05 & -0.48 \\
\hline & China & -0.10 & 2.29 & 10.49 & 14.24 & 15.86 & -14.35 & & 58.03 & 104.06 & 12.04 \\
\hline & Japan & 0.31 & 1.58 & 4.40 & 6.95 & 6.63 & -6.13 & 58.03 & & 32.53 & 5.58 \\
\hline & Korea & 4.88 & 3.24 & 12.13 & 12.12 & 15.07 & -11.05 & 104.06 & 32.53 & & 12.13 \\
\hline & World & 0.21 & 0.33 & 1.16 & 1.16 & & -0.48 & 12.04 & 5.58 & 12.13 & 0.95 \\
\hline
\end{tabular}


Table 2. The Effects of the Proposed East Asian RTAs on the Participating Economies (\% Deviation from the Base)

\begin{tabular}{|c|c|c|c|c|c|c|c|c|c|c|c|}
\hline \multirow{2}{*}{\multicolumn{2}{|c|}{ Expansionary RTA }} & \multirow{3}{*}{$\begin{array}{c}\text { Welfare (EV) } \\
2.69\end{array}$} & \multirow{3}{*}{$\begin{array}{l}\text { GDP } \\
3.77 \\
\end{array}$} & \multirow{3}{*}{$\begin{array}{c}\text { Exports } \\
2.28 \\
\end{array}$} & \multirow{3}{*}{$\begin{array}{c}\text { Imports } \\
4.25 \\
\end{array}$} & \multirow{3}{*}{$\begin{array}{c}\text { Income Terms of } \\
\text { Trade } \\
3.89 \\
\end{array}$} & \multicolumn{5}{|c|}{ Bilateral Trade } \\
\hline & & & & & & & \multirow{2}{*}{$\begin{array}{c}\text { ASEAN } \\
19.02\end{array}$} & \multirow{2}{*}{$\begin{array}{l}\text { China } \\
33.19\end{array}$} & \multirow{2}{*}{$\begin{array}{c}\text { Japan } \\
-1.51 \\
\end{array}$} & \multirow{2}{*}{$\begin{array}{c}\text { Korea } \\
-3.27\end{array}$} & \multirow{2}{*}{$\begin{array}{c}\text { World } \\
1.33\end{array}$} \\
\hline \multirow{3}{*}{ ASEAN+3 } & ASEAN & & & & & & & & & & \\
\hline & Japan & 0.25 & 1.32 & 4.77 & 6.87 & 8.08 & -1.51 & 53.14 & & 31.29 & 5.74 \\
\hline & Korea & 4.57 & 2.86 & 12.13 & 11.87 & 15.73 & -3.27 & 96.68 & 31.29 & & 12.01 \\
\hline \multicolumn{2}{|l|}{ Global RTA } & Welfare (EV) & GDP & Exports & Imports & Trade & ASEAN & China & Japan & Korea & World \\
\hline \multirow[b]{3}{*}{ APEC } & ASEAN & 2.28 & 4.59 & 5.19 & 6.67 & 10.26 & 5.24 & 41.19 & 9.87 & 9.68 & 5.93 \\
\hline & China & 0.69 & 5.49 & 21.01 & 28.65 & 32.23 & 41.19 & & 36.48 & 77.21 & 24.16 \\
\hline & Japan & 0.54 & 2.29 & 8.04 & 11.08 & 13.86 & 9.87 & 36.48 & & 19.90 & 9.44 \\
\hline
\end{tabular}


Figure 1. Aggregate Effects of East Asian RTAs by the Type of the RTA (\% Deviation from the Base)
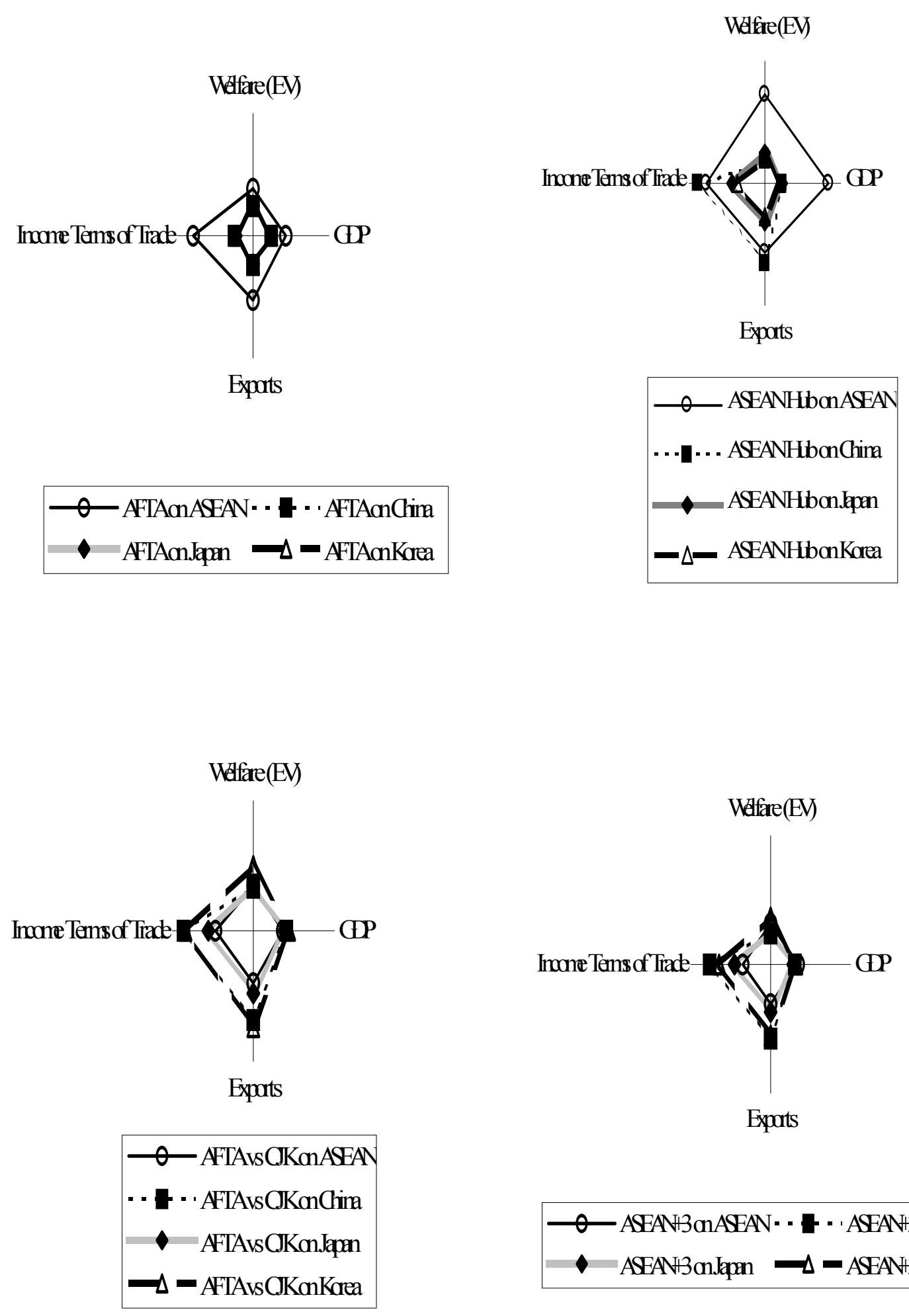

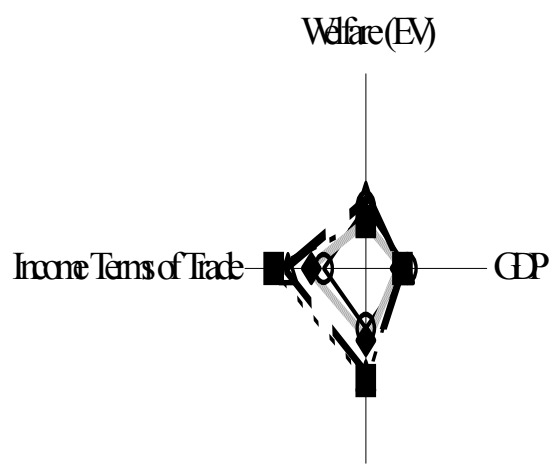

Expots

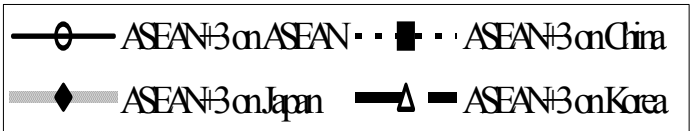


Figure 2. Aggregate Effects of East Asian RTAs by Economy (\% Deviation from the Base)

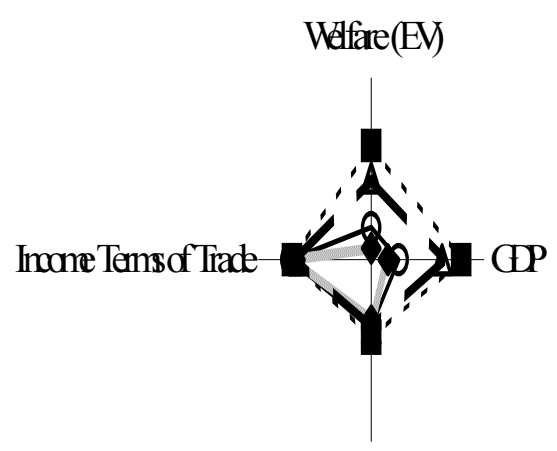

Exports

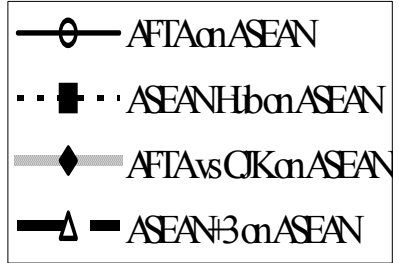

Weffere(EV)

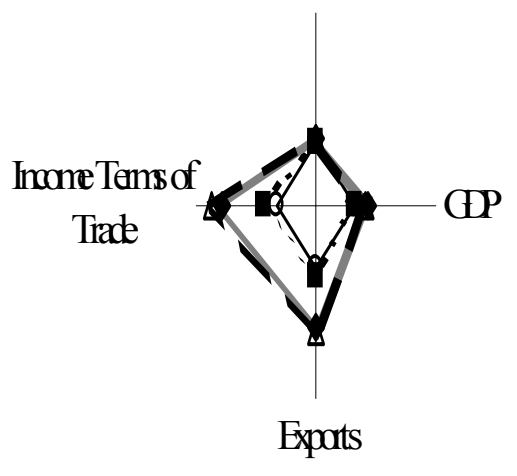

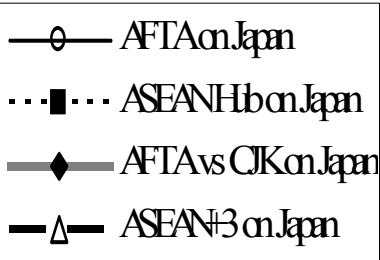

Weffare(EV)

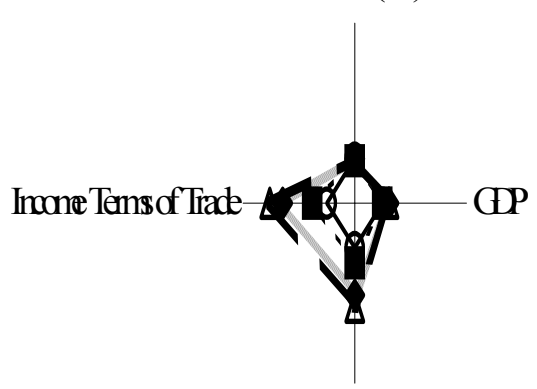

Expots

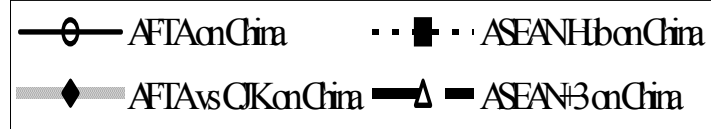

Expots

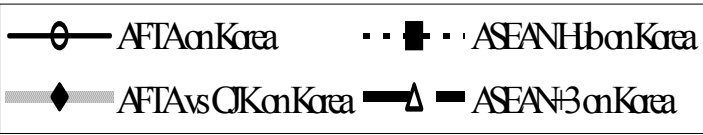


Figure 3. Aggregate Effects of East Asian RTAs by Measure (\% Deviation from the Base)

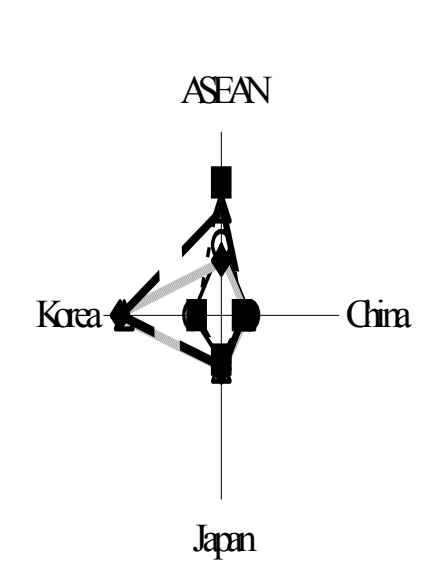

O-AFTAon Welfare
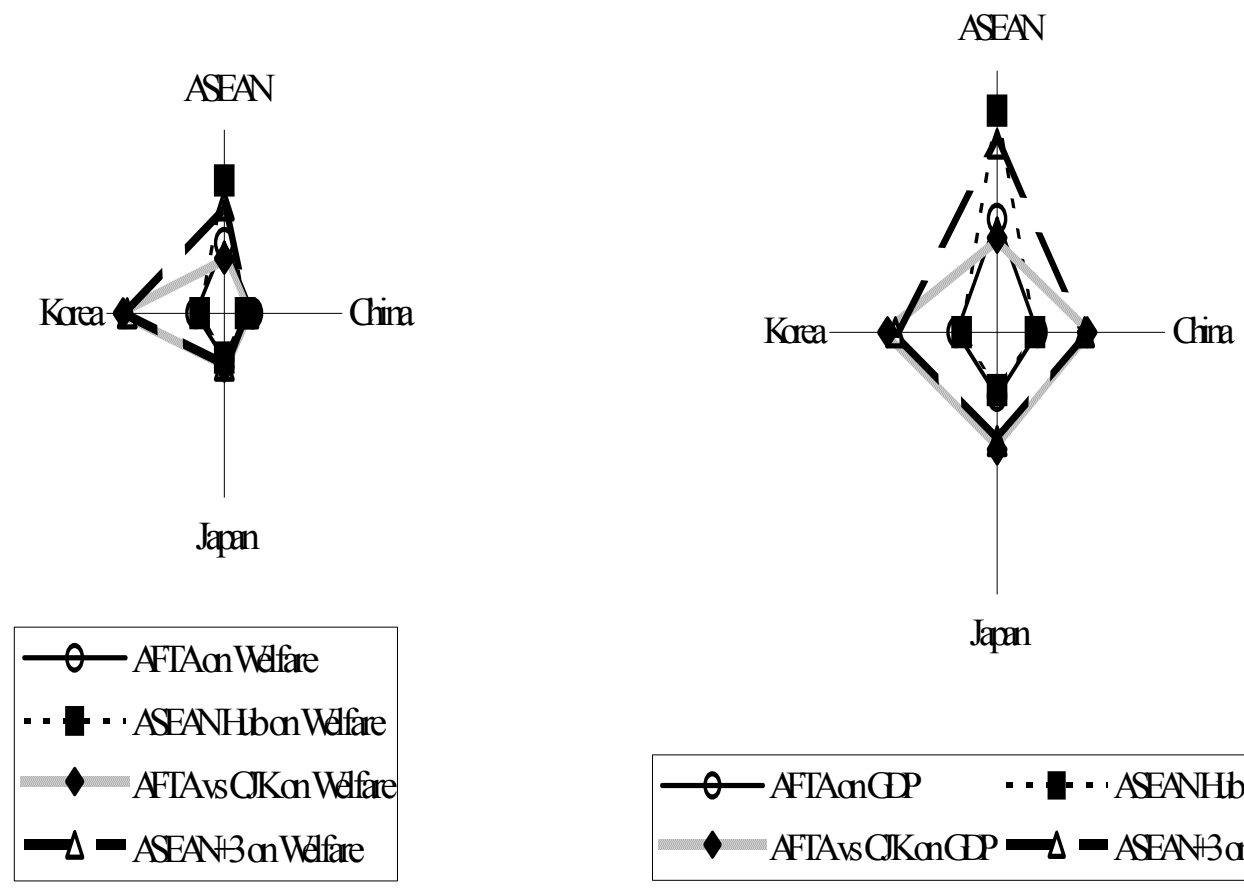

Japan

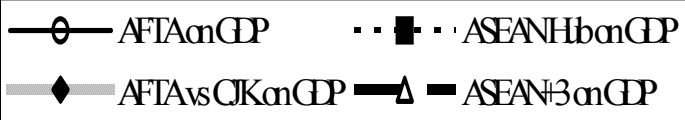
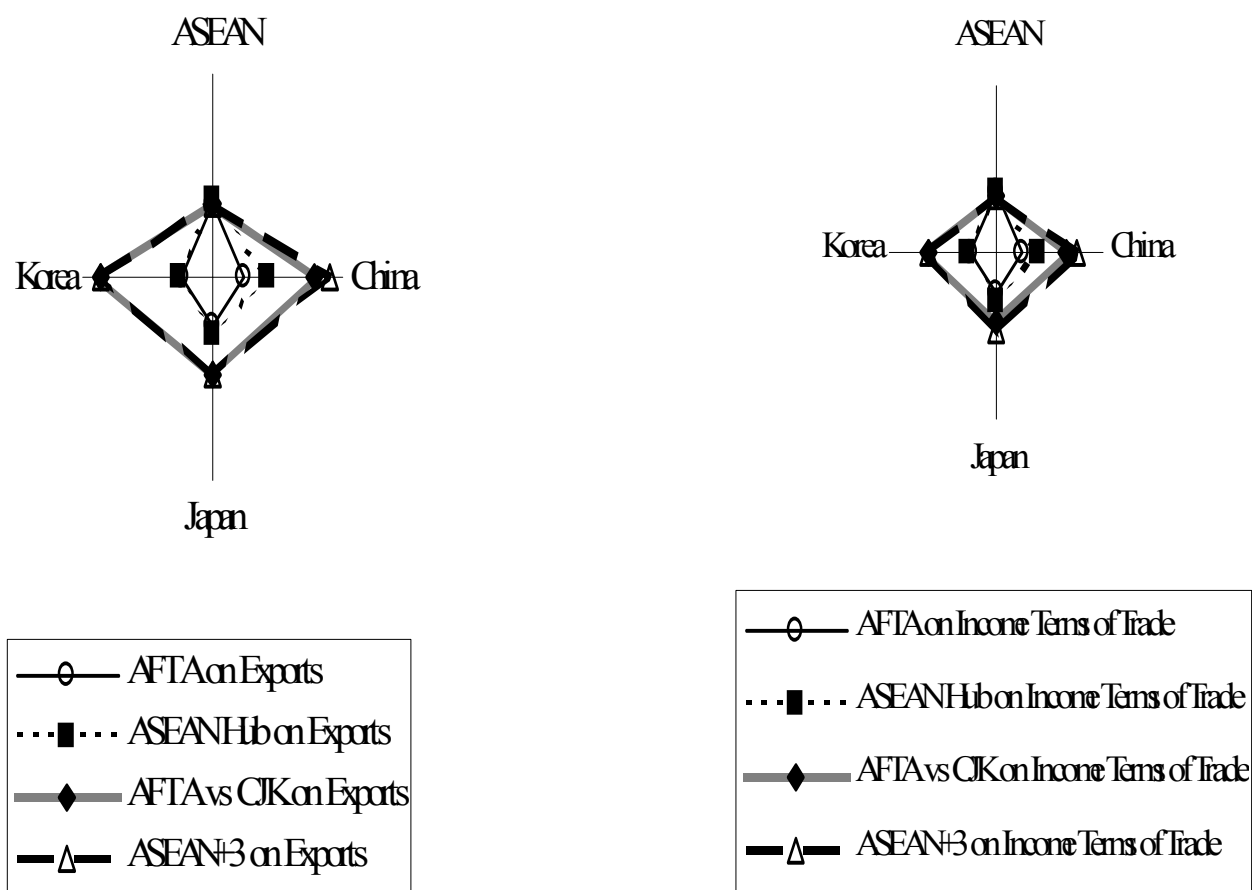
Table 3. Effects of the Proposed East Asian RTAs on Regional and Global Economies (\% Deviation from the Base)

\begin{tabular}{|c|c|c|c|c|c|c|c|c|c|c|}
\hline \multirow{2}{*}{\multicolumn{2}{|c|}{ Existing RTA }} & \multirow{3}{*}{$\begin{array}{c}\text { Welfare } \\
(\mathrm{EV}) \\
1.06\end{array}$} & \multirow{3}{*}{$\begin{array}{c}\text { GDP } \\
0.93\end{array}$} & \multirow{3}{*}{$\begin{array}{c}\text { Exports } \\
2.22\end{array}$} & \multirow{3}{*}{$\begin{array}{c}\text { Imports } \\
2.90\end{array}$} & \multicolumn{5}{|c|}{ Bilateral Trade } \\
\hline & & & & & & \multirow{2}{*}{\multicolumn{3}{|c|}{ Members (ASEAN) }} & \multirow{2}{*}{$\begin{array}{c}\text { Nonmembers } \\
-2.84\end{array}$} & \multirow{2}{*}{$\begin{array}{c}\text { World } \\
0.15\end{array}$} \\
\hline \multirow{3}{*}{ AFTA } & Members (ASEAN) & & & & & 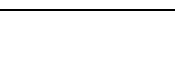 & & & & \\
\hline & Nonmembers & -0.03 & -0.02 & -0.05 & -0.06 & & -2.84 & & 0.07 & -0.15 \\
\hline & World & 0.28 & 0.01 & 0.09 & 0.09 & & 0.15 & & -0.15 & 0.08 \\
\hline \multirow{2}{*}{\multicolumn{2}{|c|}{ Overlapping RTA (Hub and Spoke) }} & \multirow{2}{*}{$\begin{array}{l}\text { Welfare } \\
(\mathrm{EV})\end{array}$} & \multirow{2}{*}{ GDP } & \multirow{2}{*}{ Exports } & \multirow{2}{*}{ Imports } & \multicolumn{5}{|c|}{ Bilateral Trade } \\
\hline & & & & & & Members & ASEAN & CJK & Nonmembers & World \\
\hline \multirow{5}{*}{ ASEAN Hub } & Members & 2.54 & 0.61 & 1.81 & 2.33 & 10.31 & 15.55 & 6.56 & -1.50 & 1.90 \\
\hline & ASEAN & 3.77 & 0.88 & 2.59 & 5.22 & 15.55 & 16.32 & 15.24 & -6.39 & 2.33 \\
\hline & CJK & -0.33 & 0.56 & 1.47 & 1.05 & 6.56 & 15.24 & -2.36 & 0.18 & 1.72 \\
\hline & Nonmembers & -0.06 & -0.06 & -0.12 & -0.13 & -1.50 & -6.39 & 0.18 & 0.09 & -0.24 \\
\hline & World & 0.98 & 0.10 & 0.29 & 0.29 & 1.90 & 2.33 & 1.72 & -0.24 & 0.24 \\
\hline \multirow{2}{*}{\multicolumn{2}{|c|}{ Duplicating (Competing) RTA }} & \multirow{2}{*}{$\begin{array}{l}\text { Welfare } \\
(\mathrm{EV})\end{array}$} & \multirow{2}{*}{ GDP } & \multirow{2}{*}{ Exports } & \multirow{2}{*}{ Imports } & \multicolumn{5}{|c|}{ Bilateral Trade } \\
\hline & & & & & & Members & ASEAN & CJK & Nonmembers & World \\
\hline \multirow{5}{*}{$\begin{array}{c}\text { AFTA vs } \\
\text { China-Japan- } \\
\text { Korea }\end{array}$} & Members & 0.78 & 2.55 & 6.23 & 7.89 & 15.54 & 0.86 & 26.04 & -3.80 & 1.77 \\
\hline & ASEAN & 0.38 & 0.85 & 2.03 & 2.34 & 0.86 & 25.02 & -9.08 & -1.35 & -0.48 \\
\hline & $\mathrm{CJK}$ & 1.70 & 2.90 & 8.02 & 10.33 & 26.04 & -9.08 & 62.15 & -4.64 & 2.75 \\
\hline & Nonmembers & -0.16 & -0.11 & -0.22 & -0.24 & -3.80 & -1.35 & -4.64 & 0.34 & -0.52 \\
\hline & World & 0.21 & 0.51 & 1.16 & 1.16 & 1.77 & -0.48 & 2.75 & -0.52 & 0.95 \\
\hline \multirow{2}{*}{\multicolumn{2}{|c|}{ Expansionary RTA }} & \multirow{2}{*}{$\begin{array}{l}\text { Welfare } \\
(\mathrm{EV})\end{array}$} & \multirow{2}{*}{ GDP } & \multirow{2}{*}{ Exports } & \multirow{2}{*}{ Imports } & \multicolumn{5}{|c|}{ Bilateral Trade } \\
\hline & & & & & & Members & ASEAN & CJK & Nonmembers & World \\
\hline \multirow{5}{*}{$\mathrm{ASEAN}+3$} & Members & 2.33 & 2.89 & 7.10 & 9.01 & 23.12 & 10.66 & 32.04 & -4.50 & 3.46 \\
\hline & ASEAN & 2.69 & 0.75 & 2.28 & 4.25 & 10.66 & 19.02 & 7.22 & -4.81 & 1.33 \\
\hline & CJK & 1.50 & 3.33 & 9.16 & 11.11 & 32.04 & 7.22 & 57.56 & -4.39 & 4.38 \\
\hline & Nonmembers & -0.18 & -0.14 & -0.28 & -0.31 & -4.50 & -4.81 & -4.39 & 0.38 & -0.64 \\
\hline & World & 0.82 & 0.57 & 1.30 & 1.30 & 3.46 & 1.33 & 4.38 & -0.64 & 1.07 \\
\hline
\end{tabular}


Table 4. Sectoral Effects of the Proposed East Asian RTAs (\% Deviation from the Base)

\begin{tabular}{|c|c|c|c|c|c|c|c|c|c|}
\hline \multicolumn{2}{|l|}{ Existing RTA } & \multirow{2}{*}{$\begin{array}{c}\text { Total } \\
\text { Output } \\
2.10\end{array}$} & \multirow{2}{*}{$\begin{array}{c}\begin{array}{c}\text { Agricultural } \\
\text { Products }\end{array} \\
-0.37\end{array}$} & \multirow{2}{*}{$\begin{array}{c}\text { Food } \\
\text { Products } \\
9.35 \\
\end{array}$} & \multirow{2}{*}{$\begin{array}{c}\text { Extractive } \\
\text { Industry } \\
0.60\end{array}$} & \multirow{2}{*}{$\begin{array}{c}\text { Light } \\
\text { Manufacturing } \\
2.53\end{array}$} & \multirow{2}{*}{$\begin{array}{c}\text { Heavy } \\
\text { Manufacturing } \\
1.15\end{array}$} & \multirow{2}{*}{$\begin{array}{c}\begin{array}{c}\text { Technology- } \\
\text { intensive } \\
\text { Manufacturing }\end{array} \\
1.87\end{array}$} & \multirow{2}{*}{$\begin{array}{r}\text { Services } \\
-0.44 \\
\end{array}$} \\
\hline \multirow{8}{*}{ AFTA } & ASEAN & & & & & & & & \\
\hline & China & 0.00 & -0.08 & -0.08 & 0.01 & 0.03 & 0.06 & 0.04 & 0.01 \\
\hline & Japan & -0.01 & 0.04 & 0.00 & 0.00 & -0.05 & -0.01 & -0.01 & 0.00 \\
\hline & Korea & -0.04 & 0.00 & -0.07 & -0.07 & -0.25 & 0.07 & 0.01 & 0.02 \\
\hline & ASEAN+3 & 1.46 & -0.27 & 6.53 & 0.41 & 1.74 & 0.82 & 1.31 & -0.31 \\
\hline & East Asia $^{*}$ & 1.20 & -0.22 & 5.35 & 0.35 & 1.40 & 0.67 & 1.09 & -0.25 \\
\hline & Rest of the World & -0.01 & -0.11 & -0.28 & 0.05 & 0.01 & 0.14 & 0.09 & 0.01 \\
\hline & World & 0.57 & -0.16 & 2.42 & 0.19 & 0.68 & 0.40 & 0.57 & -0.12 \\
\hline \multicolumn{2}{|c|}{ Overlapping RTA (Hub and Spoke) } & $\begin{array}{l}\text { Total } \\
\text { Output }\end{array}$ & $\begin{array}{l}\text { Agricultural } \\
\text { Products }\end{array}$ & $\begin{array}{c}\text { Food } \\
\text { Products }\end{array}$ & $\begin{array}{l}\text { Extractive } \\
\text { Industry }\end{array}$ & $\begin{array}{c}\text { Light } \\
\text { Manufacturing }\end{array}$ & $\begin{array}{c}\text { Heavy } \\
\text { Manufacturing }\end{array}$ & $\begin{array}{l}\text { Technology- } \\
\text { intensive } \\
\text { Manufacturing }\end{array}$ & Services \\
\hline \multirow{8}{*}{ ASEAN Hub } & ASEAN & 2.56 & 0.57 & 15.54 & 3.77 & 2.68 & -3.33 & -0.44 & -0.90 \\
\hline & China & 0.03 & -0.47 & -0.99 & -0.61 & 0.58 & 0.91 & 0.77 & 0.01 \\
\hline & Japan & -0.11 & -0.28 & -0.87 & 0.07 & -0.42 & 0.38 & 0.39 & -0.02 \\
\hline & Korea & -0.14 & -0.16 & -0.91 & -1.03 & -0.10 & 0.69 & 0.54 & -0.01 \\
\hline & ASEAN+3 & 1.77 & 0.31 & 10.60 & 2.48 & 1.89 & -2.13 & -0.14 & -0.64 \\
\hline & East Asia $^{*}$ & 1.42 & 0.29 & 8.73 & 1.97 & 1.48 & -1.81 & -0.18 & -0.52 \\
\hline & Rest of the World & -0.03 & -0.09 & -0.43 & -0.01 & -0.01 & 0.19 & 0.08 & 0.03 \\
\hline & World & 0.67 & 0.09 & 3.97 & 0.94 & 0.71 & -0.77 & -0.05 & -0.24 \\
\hline
\end{tabular}

* East Asia in this table includes ASEAN+3, Hong Kong, and Taiwan. 
Table 4. Sectoral Effects of the Proposed East Asian RTAs (\% Deviation from the Base)

\begin{tabular}{|c|c|c|c|c|c|c|c|c|c|}
\hline Duplicating $(\mathrm{C}$ & peting) RTA & $\begin{array}{c}\text { Total } \\
\text { Output }\end{array}$ & $\begin{array}{l}\text { Agricultural } \\
\text { Products }\end{array}$ & $\begin{array}{c}\text { Food } \\
\text { Products }\end{array}$ & $\begin{array}{l}\text { Extractive } \\
\text { Industry }\end{array}$ & $\begin{array}{c}\text { Light } \\
\text { Manufacturing }\end{array}$ & $\begin{array}{c}\text { Heavy } \\
\text { Manufacturing }\end{array}$ & $\begin{array}{l}\text { Technology- } \\
\text { intensive }\end{array}$ & Services \\
\hline & ASEAN & 2.02 & -0.59 & 8.05 & 0.78 & 0.95 & 2.74 & 2.56 & -0.34 \\
\hline & China & -0.06 & 3.15 & 1.76 & -1.77 & 0.57 & -2.43 & -1.63 & -0.08 \\
\hline & Japan & -0.06 & -1.76 & -0.88 & 1.07 & 0.82 & 0.35 & 0.04 & -0.04 \\
\hline AFTA vs & Korea & 7.25 & -20.92 & 53.98 & 6.73 & 22.53 & -5.28 & -5.66 & -0.65 \\
\hline Korea & $\mathrm{ASEAN}+3$ & 2.13 & -2.37 & 11.12 & 1.15 & 3.06 & 1.18 & 1.07 & -0.32 \\
\hline & East Asia ${ }^{*}$ & 1.60 & -2.00 & 9.06 & 0.89 & 1.82 & 0.87 & 0.79 & -0.23 \\
\hline & Rest of the World & -0.04 & -0.57 & -0.87 & 0.14 & -0.69 & 0.94 & 0.72 & 0.04 \\
\hline & World & 0.75 & -1.25 & 3.89 & 0.50 & 0.51 & 0.91 & 0.75 & -0.09 \\
\hline Expansionary I & & $\begin{array}{c}\text { Total } \\
\text { Output }\end{array}$ & $\begin{array}{l}\text { Agricultural } \\
\text { Products }\end{array}$ & $\begin{array}{c}\text { Food } \\
\text { Products }\end{array}$ & $\begin{array}{l}\text { Extractive } \\
\text { Industry }\end{array}$ & $\begin{array}{c}\text { Light } \\
\text { Manufacturing }\end{array}$ & $\begin{array}{c}\text { Heavy } \\
\text { Manufacturing }\end{array}$ & $\begin{array}{l}\text { Technology- } \\
\text { intensive } \\
\text { Manufacturing }\end{array}$ & Services \\
\hline & ASEAN & 2.44 & 0.36 & 13.79 & 3.76 & 0.86 & -1.27 & 0.30 & -0.74 \\
\hline & China & -0.06 & 2.80 & 0.78 & -2.29 & 0.99 & -1.70 & -0.95 & -0.06 \\
\hline & Japan & -0.16 & -2.03 & -1.65 & 0.97 & 0.44 & 0.78 & 0.42 & -0.06 \\
\hline$\triangle \mathrm{SF} \triangle \mathrm{N}+3$ & Korea & 6.93 & -21.16 & 51.50 & 5.23 & 22.93 & -4.37 & -4.95 & -0.66 \\
\hline ADEAIVTJ & ASEAN+3 & 2.38 & -1.79 & 14.72 & 3.02 & 3.04 & -1.41 & -0.34 & -0.59 \\
\hline & East Asia ${ }^{*}$ & 1.79 & -1.49 & 12.06 & 2.38 & 1.80 & -1.35 & -0.43 & -0.46 \\
\hline & Rest of the World & -0.06 & -0.53 & -0.95 & 0.09 & -0.69 & 0.91 & 0.68 & 0.05 \\
\hline & World & 0.83 & -0.99 & 5.30 & 1.19 & 0.51 & -0.17 & 0.14 & -0.19 \\
\hline
\end{tabular}

* East Asia in this table includes ASEAN+3, Hong Kong, and Taiwan. 
Table 5. The Sustainability Test for RTAs in East Asia

\begin{tabular}{|c|c|c|c|c|c|c|}
\hline & Condition & for the Sustainability Test & AFTA & $\begin{array}{c}\text { ASEAN } \\
\text { Hub }\end{array}$ & $\begin{array}{c}\text { AFTA } \\
\text { Vs } \\
\text { China- }\end{array}$ & ASEAN +3 \\
\hline & & Consumption (EV of Welfare) & + & ++ & + & ++ \\
\hline & & Production (GDP) & + & +++ & + & ++ \\
\hline & 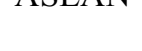 & Volume of Trade (Exports and Imports) & ++ & +++ & ++ & ++ \\
\hline & & Terms of Trade (Income TOT) & +++ & +++ & +++ & ++ \\
\hline & & Consumption (EV of Welfare) & & - & - & - \\
\hline & & Production (GDP) & & - & ++ & ++ \\
\hline & & Volume of Trade (Exports and Imports) & & ++ & +++ & +++ \\
\hline Individual & & Terms of Trade (Income TOT) & & +++ & +++ & +++ \\
\hline Economy & & Consumption (EV of Welfare) & & $*$ & + & + \\
\hline & Janan & Production (GDP) & & - & + & + \\
\hline & & Volume of Trade (Exports and Imports) & & + & +++ & +++ \\
\hline & & Terms of Trade (Income TOT) & & + & +++ & +++ \\
\hline & & Consumption (EV of Welfare) & & - & +++ & +++ \\
\hline & Koro & Production (GDP) & & - & ++ & ++ \\
\hline & Novea & Volume of Trade (Exports and Imports) & & $*$ & +++ & +++ \\
\hline & & Terms of Trade (Income TOT) & & + & +++ & +++ \\
\hline & & Consumption (EV of Welfare) & + & ++ & + & ++ \\
\hline Members o & Average & Production (GDP) & + & + & ++ & ++ \\
\hline & & Volume of Trade (Exports and Imports) & ++ & ++ & +++ & +++ \\
\hline & & Consumption (EV of Welfare) & $*$ & $*$ & - & - \\
\hline $\begin{array}{r}\text { Nonmen } \\
\text { Ave }\end{array}$ & $\begin{array}{l}\text { ers on } \\
\text { ge }\end{array}$ & Production (GDP) & $*$ & * & - & - \\
\hline & & Volume of Trade (Exports and Imports) & * & - & - & - \\
\hline & & Consumption (EV of Welfare) & + & + & + & + \\
\hline World E & nomy & Production (GDP) & $*$ & + & + & + \\
\hline & & Volume of Trade (Exports and Imports) & $*$ & + & + & + \\
\hline Distributio & of Gains & Overall Evaluation Between Members & & $\mathrm{NE}$ & $\mathrm{NE}$ & $\mathrm{E}$ \\
\hline & & Consumption (EV of Welfare) & & NH & $\mathrm{NH}$ & $\mathrm{NH}$ \\
\hline Pareto E & ciency & Production (GDP) & & $\mathrm{NH}$ & NH & $\mathrm{H}$ \\
\hline relative $\mathrm{t}$ & AFTA & Volume of Trade (Exports and Imports) & & $\mathrm{H}$ & $\mathrm{NH}$ & $\mathrm{H}$ \\
\hline & & Terms of Trade (Income TOT) & & NH & $\mathrm{NH}$ & $\mathrm{NH}$ \\
\hline
\end{tabular}

Notes: + (positive), ++ (significantly positive), +++ (strongly positive), * (insignificant), (negative) where $0.1 \% \leq+<2 \% ; 2 \% \leq++<4 \% ; 4 \% \leq+++;-0.1 \%<*<0.1 \% ;-$ $1 \% \leq-\leq-0.1 \%$.

E (NE): Evenly (Not Evenly) distributed

$\mathrm{H}(\mathrm{NH})$ : Hold (Not Hold) 